\title{
Organic-Photoacid-Catalyzed Glycosylation
}

\author{
Juncheng Li \\ Gaoyuan Zhao \\ Ting Wang* (D)
}

Department of Chemistry, University at Albany, State University of New York, 1400 Washington Avenue, Albany, New York 12222, USA twang3@albany.edu

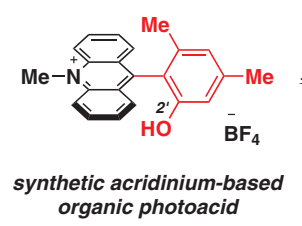

visible light organic photoacid<smiles>O=C1OC2(c3ccccc31)c1cc(Br)c(O)c(Br)c1Oc1c2cc(Br)c(O)c1Br</smiles>

commercially available Eosin $Y$

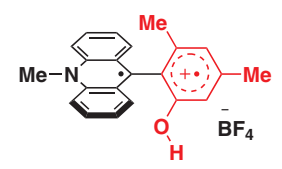

photoacidic activity

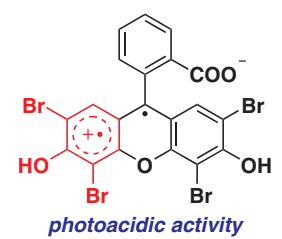

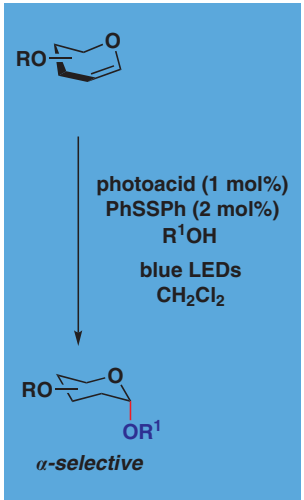

Received: 12.11.2019

Accepted after revision: 29.11.2019

Published online: 10.01 .2020

DOI: 10.1055/s-0039-1690773; Art ID: st-2019-p0614-sp

\begin{abstract}
Photoacids are molecules that become more acidic upon absorption of light. They are widely utilized in a variety of fields, such as organic synthesis, molecular switching agents, and photodynamic therapy. Currently, the activity of most photoacids is induced by UV light, which limits their applications by the synthetic community. In this Synpacts article, we highlight our recent development of visible-lightinduced photoacids and their application in glycosylation reactions.

1 Introduction

2 Visible-Light-Induced Photoacids

3 Synthesis of 2-Deoxyglycosides by Visible-Light-Induced Photoacid Catalysis

4 Conclusion
\end{abstract}

Key words photoacids, glycosylation, 2-deoxyglycosides, visible-light, photocatalysis

\section{Introduction}

Brønsted acid catalyzed reactions are among the most important and practical transformations of organic molecules..$^{1-3}$ Many reactions such as acylation, alkylation, cycloaddition, glycosylation, and polymerization are promoted by acid catalysis, and are used in the industrial production of pharmaceuticals, agrochemicals, organic materials, and fine and bulk chemicals. Differing from traditional Brønsted acids, photoacids are molecules that are neutral in the ground state and show enhanced acidity only upon irradiation with light. ${ }^{4}$ Photoacids have been utilized in polymer synthesis, ${ }^{5}$ proton-transfer processes, ${ }^{6}$ acid-catalyzed reactions, ${ }^{7}$ molecular switching events, ${ }^{8}$ and photodynamic therapy. ${ }^{9}$ In particular, phenol, naphthol, and thiourea derivatives have been used as photoacids to catalyze glycosylation reactions (Scheme 1). In 2014, Toshima reported a photoinduced glycosylation using phenol and naphthol derivatives 1-4 as photoacids (Scheme 1$)^{7 \mathrm{e}}$ The organic pho-

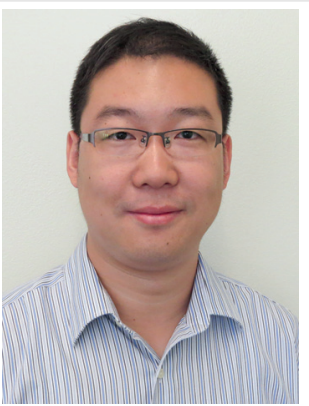

Ting Wang graduated from Tianjin University in Tianjin, China, where he undertook undergraduate research in the laboratory of Prof. John Reiner. In the fall of 2005, he joined Prof. Craig Forsyth's group for graduate studies in natural product synthesis and earned his Ph.D. from The Ohio State University in 2011. For his postdoctoral work, Ting pursued studies in the field of peptide and protein synthesis, working with Prof. Samuel Danishefsky at the Memorial Sloan-Kettering Cancer Center. Ting began his academic career as an assistant professor in the Department of Chemistry at the State University of New York (SUNY-Albany) in 2015. His research activities are directed toward the exploration of new synthetic opportunities through visible-light photocatalysis, including designing new photocatalysts, understanding their unique photoactivities, and developing novel synthetic strategies. The newly developed synthetic strategies will be further applied in the synthesis of biologically active small molecules, peptides, and carbohydrates.

toacids could effectively catalyze the glycosylation reactions of glycosyl trichloroacetimidates and alcohols to give the corresponding glycosides in high yields. The organic photoacid could be recovered and reused without any loss of efficiency. More recently, Toshima's group has reported another photoacid-catalyzed glycosylation, where they employed thiourea derivative 5 as a photoacid. ${ }^{7 f}$ These two unprecedented examples of photoacid-catalyzed glycosylation have drawn our attention to the field of new photoacid design and their potential application in glycosylation reactions. 
Toshima's photoinduced glycosylation

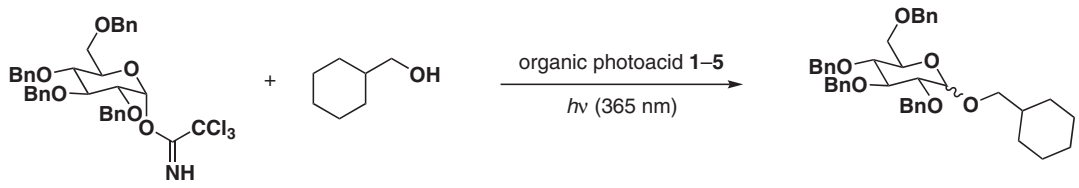<smiles>Oc1ccc2ccccc2c1</smiles><smiles>OCc1cccc(O)c1</smiles><smiles>N#Cc1cccc2cc(O)ccc12</smiles><smiles>N#Cc1ccc(O)c2ccc(O)cc12</smiles><smiles>FC(F)(F)c1cc(NC(=S)Nc2cc(C(F)(F)F)cc(C(F)(F)F)c2)cc(C(F)(F)F)c1</smiles>

Scheme 1 Photoinduced glycosylation and the structures of known photoacids

\section{Visible-Light-Induced Photoacids}

Photoacids have shown their unique activities in organic reactions. However, most of them only absorb UV light to achieve their excited state, which requires expensive, specialized UV photochemical equipment. In addition, UV irradiation is not always compatible with many functional groups employed in organic synthesis. Our interest was to design and synthesize a new class of photoacid that can absorb visible light. Thus, we were drawn to phenolic derivatives (i.e., phenol, naphthol), which have been shown to exhibit marked increases in acidity upon light irradiation. Our catalyst design relies on the skeleton of the 9-mesityl-10methylacridinium ion (A), which is a novel photoredox catalyst reported by Fukuzumi in $2004 .{ }^{10}$ Electron reorganization of the catalyst upon light irradiation $\left(\mathbf{A}^{*}\right)$ results in the radical cation species of the mesitylene moiety, which exhibits a high single-electron oxidation potential. Recently, studies on the development of acridinium-based photoredox catalysts have shown that the structure modification impacts catalyst excitation, emission, and excited state lifetimes. ${ }^{11}$ Inspired by these results, our entry into the field began with the design and synthesis of the acridiniumbased, phenol-substituted compound B (Scheme 2). Catalyst B was minimally modified by direct substitution with a hydroxy group at the 2'-position, resulting in a phenolic variant of the Fukuzumi catalyst $\mathbf{A}$. In the excited state (i.e., $\left.\mathbf{B} \rightarrow \mathbf{B}^{*}\right)$, we proposed that the radical cation phenol moiety might exhibit increased acidity. With the early success of synthetic catalyst B, we also included commercially available Eosin $\mathrm{Y}(\mathbf{C})$ in the studies of this ArOH-type photoacid catalysis. $^{12}$

\section{Synthesis of 2-Deoxyglycosides by Visible- Light-Induced Photoacid Catalysis}

With the synthetic photoacid $\mathbf{B}$ in hand, we were interested in applying the photoacid for the synthesis of carbohydrates, such as 2-deoxysugars. 2-Deoxysugars are widely

represented carbohydrates among biologically active natural products. ${ }^{13,14}$ In particular, the 2-deoxyglycoside motif often plays an essential role in the corresponding biological activity of the parent molecules. ${ }^{15,16}$ The importance of such 2-deoxysugars has made them attractive targets in the carbohydrate community, resulting in considerable efforts toward the synthesis of 2-deoxyglycosides in recent years. ${ }^{17}$ However, the stereoselective synthesis of 2-deoxyglycosides remains a major challenge in this context. The absence of a stereo-directing functionality at the $\mathrm{C}-2$ position makes it extremely hard to control the stereo-outcomes in the glycosylation step. The temporary installation of a directing group at C-2 was helpful in certain cases; however, this approach required extra steps in the synthesis. ${ }^{18}$ The reported

Visible-light-induced photoacids

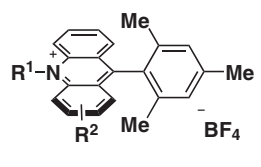

Acr-Mes ion (A)

Fukuzumi ${ }^{10}$

Nicewicz \& DiRocco ${ }^{11}$

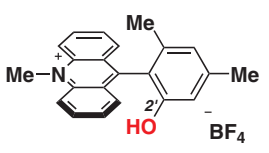

blue LEDs (450 $\mathrm{nm})$

B

our synthetic photoacid

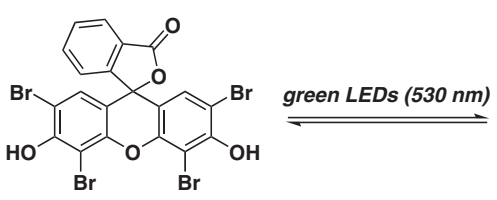

commercially available Eosin Y (C)

Scheme 2 Visible-light-induced photoacids 
direct routes to 2-deoxyglycosides rely on stoichiometric promoters or synthetic precursors that require several steps to prepare. ${ }^{19}$ Therefore, catalytic addition of an alcohol to a glycal is still considered the most efficient way to prepare 2-deoxyglycosides..$^{20,21}$ After extensive optimization of the reaction conditions, we found a co-catalyst system that worked best in this glycosylation. Our synthetic photoacid B could efficiently deliver the desired 2-deoxysugar 3 in 75\% yield, while commercially available Eosin Y also gave the desired product with a slightly better yield (90\%) (Scheme 3). Mechanistically, we propose that upon light irradiation, the excited photocatalyst ( $\left.\mathbf{P C}^{*}\right)$ would serve as an acid, protonating the glycal 4 . The resulting oxocarbenium intermediate 5 was intercepted by ROH to afford intermediate $\mathbf{6}$, which would be converted into the 2-deoxysugar 7 through a proton transfer process (with 13). The deprotonated photocatalyst $\mathbf{8}$ would undergo a single-electron transfer process with $\mathrm{PhS}^{-}(\mathbf{1 2})$, furnishing 9 and $\mathrm{PhS}^{-}$ (13). $\mathrm{PhS}^{-}$(13) could serve as a base to facilitate the proton transfer step with $\mathbf{6}$, producing $\mathrm{H}$-atom donor $\mathrm{PhSH}$ (14). Intermediate $\mathbf{1 0}$, a resonance structure of $\mathbf{9}$, would abstract
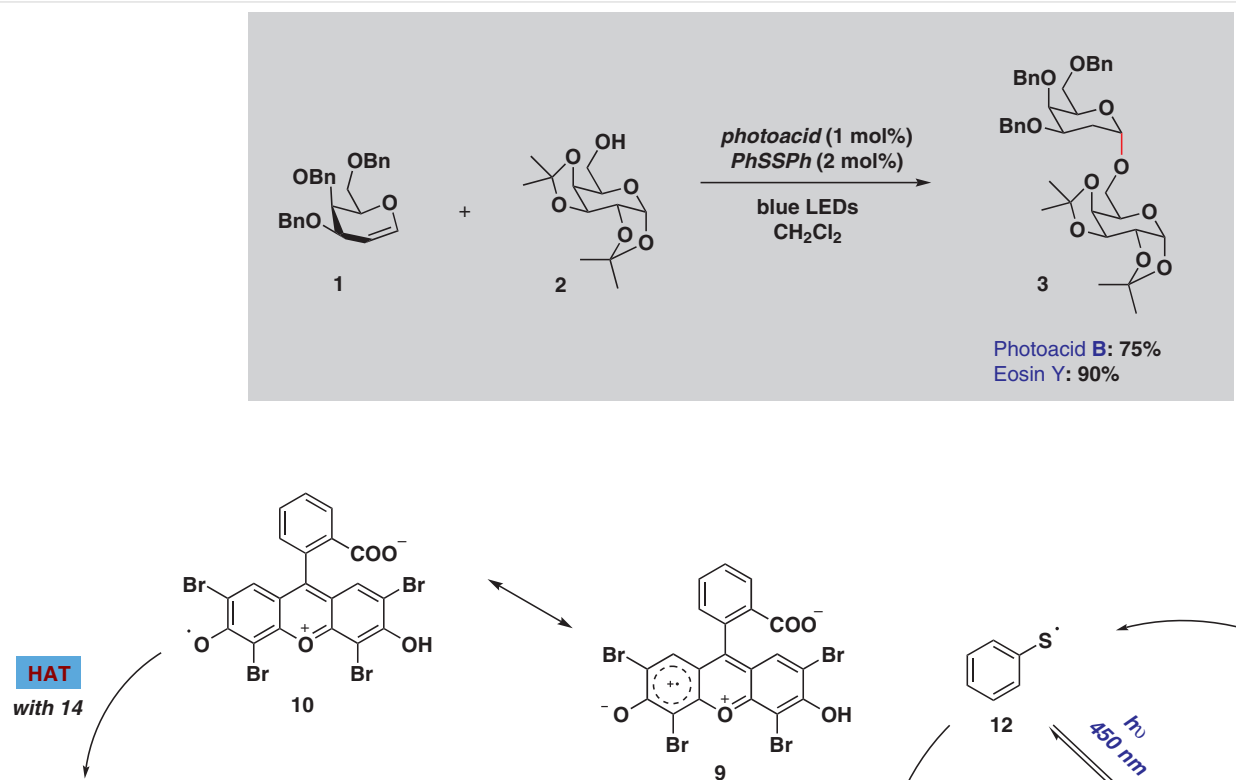

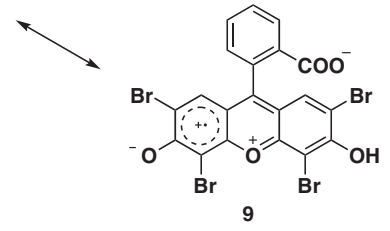<smiles></smiles>

photocatalyst (PC)<smiles>C#CC(=O)O[Mg]</smiles>

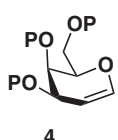

$=$ Proton Transfer

HAT $=\mathrm{H}$-Atom Transfer

$\pm \mathrm{e}^{-}=$Redox Couple
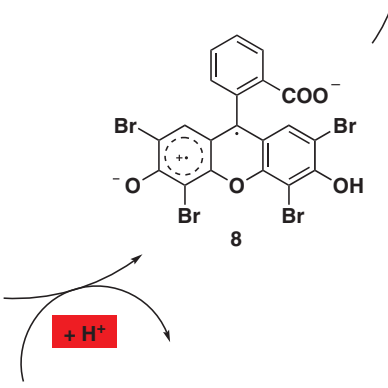

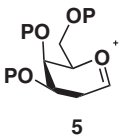

Scheme 3 Proposed mechanism
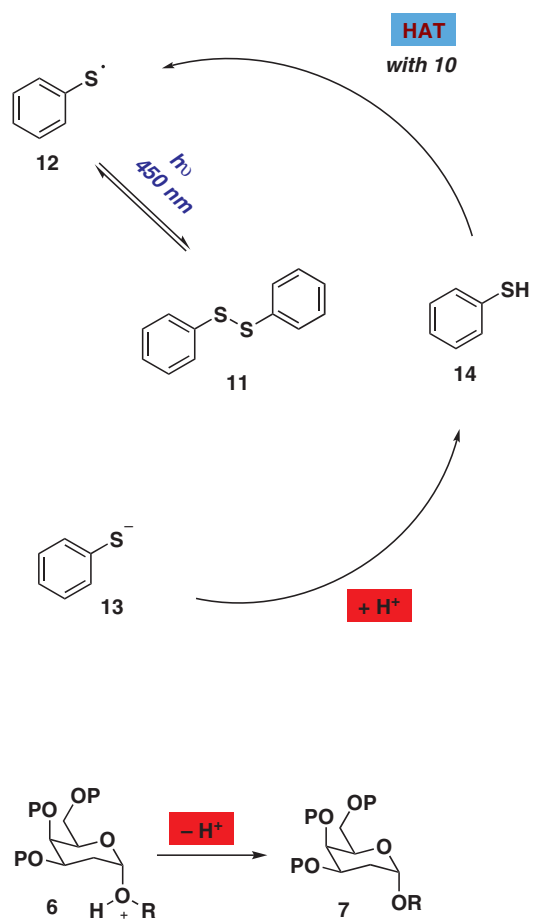
a hydrogen atom from $\mathrm{PhSH}(\mathbf{1 4})$ to regenerate the photocatalyst (PC) and $\mathrm{PhS}^{*}(\mathbf{1 2})$.

With optimized reaction conditions in hand, the scope of the reaction was explored. A range of alcohols reacted with perbenzyl galactal 1 smoothly, providing the corresponding 2-deoxyglycosides in excellent yields (67-91\%) and with remarkable $\alpha$-selectivity (16:1, $\alpha$ only). The reaction conditions tolerated substrates with common alcohol and amine protecting groups (16-24). Excitingly, high efficiency and stereoselectivity were maintained regardless of the glycosyl acceptor type or the positioning of the accepting hydroxy group. In addition, $N$-Boc-protected serine, cholesterol and a protected nucleotide also underwent the glycosylation to provide the corresponding products 22-24 in good yields. A major challenge of the current synthetic strategy toward the direct synthesis of 2-deoxysugars from glycals is the difficulty of suppressing the Ferrier-type byproducts 15 (Scheme 4). In particular, glycals bearing C-3 acetates were difficult substrates toward such glycosylation reactions, with numerous Brønsted acids, Lewis acids, and organometallic catalysts all having failed in this process. Excitingly, the unique activity of the photoacid $\mathbf{C}$ led to the successful conversion of the peracetyl galactal $\mathbf{2 5}$ into the corresponding 2-deoxyglycosides 26-32 in good yields and with excellent $\alpha$-selectivity. We proposed that the transient nature of the photoacids would prefer kinetic protonation of the vinyl ether moiety, which would result in the formation of the glycosylation product. Studies toward a more indepth understanding of the reactivity of such photoacids are ongoing in our laboratory.

To test the scope of the glycal donors, we prepared a series of differently protected galactals $\mathbf{3 3 a}-\mathbf{c}$, L-rhamnals 33d-f, and glucals 1 and 33g-k. Thus, 12 donors were subjected to the photocatalytic conditions with glycosyl acceptor $\mathbf{2}$ in the presence of Eosin Y, providing the corresponding $\alpha$-linked 2-deoxyglycosides in high yields (66-93\%) and excellent selectivity $(\alpha / \beta$ ratio $=16: 1$ to $>30: 1)$. A range of functional groups in the glycals $\mathbf{3 3}$ was tolerated, such as methoxymethyl, benzyl, silyl, allyl ethers, and acetyl esters (Scheme 5).

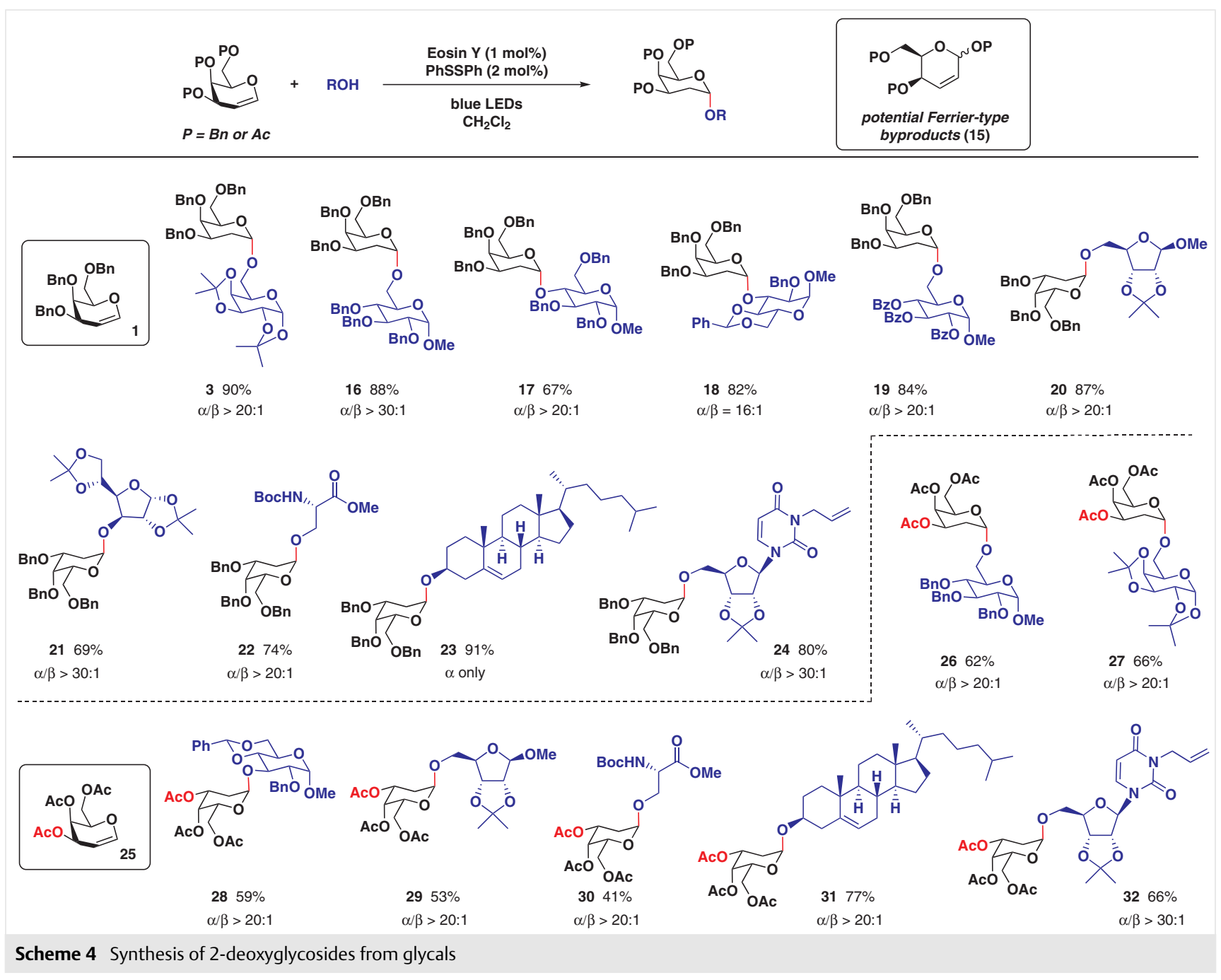




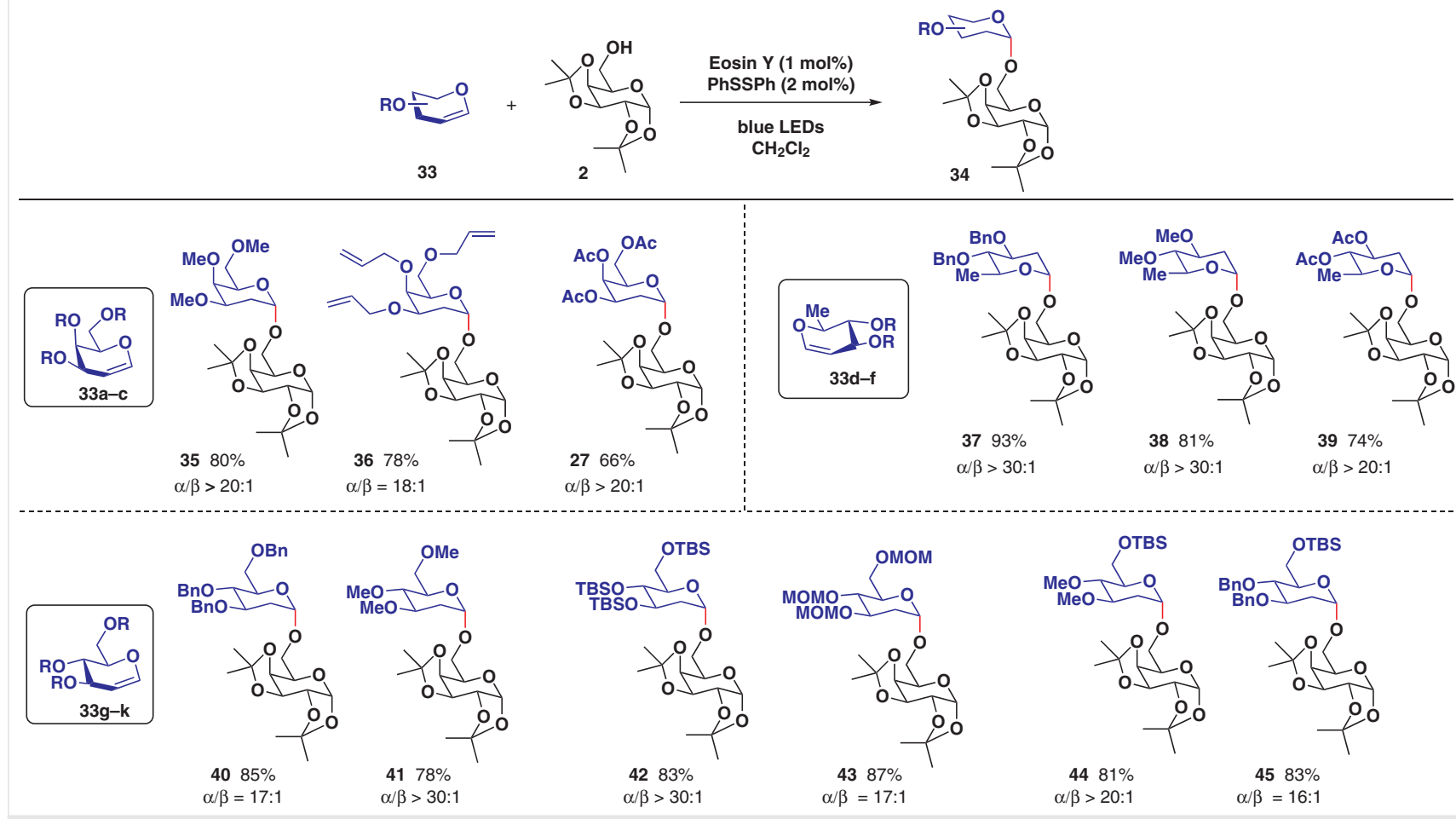

Scheme 5 Scope of the glycal donors

\section{Conclusion}

In summary, we have designed and synthesized a new visible-light-induced photoacid. The commercially available Eosin Y was then applied for the direct preparation of 2-deoxyglycosides from glycals. The photoacid catalysis enabled glycosylation between a range of hydroxy nucleophiles and glycals, providing the corresponding 2-deoxyglycosides in excellent yields and with $\alpha$-selectivity. Further synthetic applications and in-depth mechanistic studies with regard to organic photoacids are ongoing in our laboratory.

\section{Funding Information}

Financial support was provided by the State University of New York at Albany.

\section{Acknowledgement}

My sincere thanks go to my co-workers, Juncheng Li and Dr. Gaoyuan Zhao, who made this research possible.

\section{References}

(1) Min, C.; Seidel, D. Chem. Soc. Rev. 2017, 46, 5889.

(2) Monaco, M.; Pupo, G.; List, B. Synlett 2016, 27, 1027.
(3) Bolm, C.; Rantanen, T.; Schiffers, I.; Zani, L. Angew. Chem. Int. Ed. 2005, 44, 1758.

(4) (a) Tolbert, L. M.; Solntsev, K. M. Acc. Chem. Res. 2002, 35, 19. (b) Tolbert, L. M.; Haubrich, J. E. J. Am. Chem. Soc. 1990, 112, 8163. (c) Tolbert, L. M.; Haubrich, J. E. J. Am. Chem. Soc. 1994, 116, 10593.

(5) (a) Liao, Y. Acc. Chem. Res. 2017, 50, 1956. (b) Ivan, M. G.; Scaiano, J. C. Photoimaging and Lithographic Processes in Polymers, In Photochemistry and Photophysics of Polymer Materials; Allen, N. S., Ed.; John Wiley \& Sons: Hoboken, 2010.

(6) (a) Ireland, J. F.; Wyatt, P. A. H. Adv. Phys. Org. Chem. 1976, 12, 131. (b) Shizuka, H. Acc. Chem. Res. 1985, 18, 141.

(7) (a) Yi, H.; Niu, L.; Wang, S.; Liu, Y.; Singh, A. K.; Lei, A. Org. Lett. 2017, 19, 122. (b) Oates, R. P.; Jones, P. B. J. Org. Chem. 2008, 73, 4743. (c) Shi, Z.; Peng, P.; Strohecker, D.; Liao, Y. J. Am. Chem. Soc. 2011, 133, 14699. (d) Serafinowski, P. J.; Garland, P. B. J. Am. Chem. Soc. 2003, 125, 962. (e) Iwata, R.; Uda, K.; Takahashi, D.; Toshima, K. Chem. Commun. 2014, 50, 10695. (f) Kimura, T.; Eto, T.; Takahashi, D.; Toshima, K. Org. Lett. 2016, 18, 3190. (g) Das, A.; Banerjee, T.; Hanson, K. Chem. Commun. 2016, 52, 1350. (h) Das, A.; Ayad, S.; Hanson, K. Org. Lett. 2016, 18, 5416. (i) Yan, D.-M.; Chen, J.-R.; Xiao, W.-J. Angew. Chem. Int. Ed. 2019, 58, 378. (j) Strada, A.; Fredditori, M.; Zanoni, G.; Protti, S. Molecules 2019, 24, 1318. (k) Salem, Z. M.; Saway, J.; Badillo, J. J. Org. Lett. 2019, 21, 8528.

(8) Tatum, L. A.; Foy, J. T.; Aprahamian, I. J. Am. Chem. Soc. 2014, $136,17438$.

(9) Yue, X.; Yanez, C. O.; Yao, S.; Belfield, K. D. J. Am. Chem. Soc. 2013, 135, 2112.

(10) Fukuzumi, S.; Kotani, H.; Ohkubo, K.; Ogo, S.; Tkachenko, N. V.; Lemmetyinen, H. J. Am. Chem. Soc. 2004, 126, 1600. 
(11) Joshi-Pangu, A.; Lévesque, F.; Roth, H. G.; Oliver, S. F.; Campeau, L.; Nicewicz, D. A.; DiRocco, D. A. J. Org. Chem. 2016, 81, 7244.

(12) Zhao, G.; Wang, T. Angew. Chem. Int. Ed. 2018, 57, 6120.

(13) Kirschning, A.; Bechthold, A. F. W.; Rohr, J. Top. Curr. Chem. 1997, $188,1$.

(14) Daniel, P. T.; Koert, U.; Schuppan, J. Angew. Chem. Int. Ed. 2006, $45,872$.

(15) Weymouth-Wilson, A. C. Nat. Prod. Rep. 1997, 14, 99.

(16) McCranie, E. K.; Bachmann, B. O. Nat. Prod. Rep. 2014, 31, 1026.

(17) (a) Marzabadi, C. H.; Franck, R. W. Tetrahedron 2000, 56, 8385. (b) Hou, D. J.; Lowary, T. L. Carbohydr. Res. 2009, 344, 1911. (c) Borovika, A.; Nagorny, P. J. Carbohydr. Chem. 2012, 31, 255. (d) Medina, S.; Galan, M. C. Carbohydr. Chem. 2015, 41, 59. (e) Zeng, J.; Xu, Y.; Wang, H.; Meng, L.; Wan, Q. Sci. China Chem. 2017, 60, 1162. (f) Benito-Alifonso, B.; Galan, M. C. Bronsted and Lewis Acid Catalyzed Glycosylation, In Selective Glycosylations: Synthetic Methods and Catalysts; Bennet, C. S., Ed.; Wiley-VCH: Weinheim, 2017. (g) Williams, R.; Galan, M. C. Eur. J. Org. Chem. 2017, 6247. (h) Bennett, C. S.; Galan, M. C. Chem. Rev. 2018, 118, 7931.

(18) (a) Thiem, J.; Gerken, M.J. Org. Chem. 1985, 50, 954. (b) Wiesner, K.; Tsai, T. Y. R.; Jin, H. Helv. Chim. Acta 1985, 68, 300. (c) Nicolaou, K. C.; Ladduwahetty, T.; Randall, J. L.; Chucholowski, A. J. Am. Chem. Soc. 1986, 108, 2466. (d) Ito, Y.; Ogawa, T. Tetrahedron Lett. 1987, 28, 2723. (e) Preuss, R.; Schmidt, R. R. Synthesis 1988, 694. (f) Perez, M.; Beau, J.-M. Tetrahedron Lett. 1989, 30, 75. (g) Gervay, J.; Danishefsky, S. J.J. Org. Chem. 1991, 56, 5448. (h) Grewal, G.; Kaila, N.; Franck, R. W. J. Org. Chem. 1992, 57, 2084. (i) Roush, W. R.; Sebesta, D. P.; Bennett, C. E. Tetrahedron 1997, 53, 8825. (j) Roush, W. R.; Sebesta, D. P.; James, R. A. Tetrahedron 1997, 53, 8837. (k) Franck, R. W.; Marzabadi, C. H. J. Org. Chem. 1998, 63, 2197. (l) Roush, W. R.; Bennett, C. E. J. Am. Chem. Soc. 1999, 121, 3541. (m) Roush, W. R.; Gung, B. W.; Bennett, C. E. Org. Lett. 1999, 1, 891. (n) Yu, B.; Wang, P. Org. Lett. 2002, 4, 1919. (o) Blanchard, N.; Roush, W. R. Org. Lett. 2003, 5, 81. (p) Bucher, C.; Gilmour, R. Angew. Chem. Int. Ed. 2010, 49, 8724. (q) Meyerhoefer, T. J.; Kershaw, S.; Caliendo, N.; Eltayeb, S.; Hanawa-Romero, E.; Bykovskaya, P.; Huang, V.; Marzabadi, C. H.; De Castro, M. Eur. J. Org. Chem. 2015, 2457.

(19) (a) Baryal, K. N.; Zhu, D.; Li, X.; Zhu, J. Angew. Chem. Int. Ed. 2013, 52, 8012. (b) Kaneko, M.; Herzon, S. B. Org. Lett. 2014, 16, 2776. (c) Pradhan, T. K.; Lin, C. C.; Mong, K. K. T. Org. Lett. 2014, 16, 1474. (d) Issa, J. P.; Bennett, C. S. J. Am. Chem. Soc. 2014, 136,
5740. (e) Wang, H.; Tao, J.; Cai, X.; Chen, W.; Zhao, Y.; Xu, Y.; Yao, W.; Zeng, J.; Wan, Q. Chem. Eur. J. 2014, 20, 17319. (f) Song, W.; Zhao, Y.; Lynch, J. C.; Kim, H.; Tang, W. Chem. Commun. 2015, 51, 17475. (g) Das, S.; Pekel, D.; Neudorfl, J. M.; Berkessel, A. Angew. Chem. Int. Ed. 2015, 54, 12479. (h) Nogueira, J. M.; Bylsma, M.; Bright, D. K.; Bennett, C. S. Angew. Chem. Int. Ed. 2016, 55, 10088. (i) Tanaka, H.; Yoshizawa, A.; Takahashi, T. Angew. Chem. Int. Ed. 2007, 46, 2505. (j) Verma, V. P.; Wang, C. C. Chem. Eur. J. 2013, 19, 846. (k) Zhu, D.; Adhikara, S.; Baryal, K. N.; Abdullah, B. N.; Zhu, J. J. Carbohydr. Chem. 2014, 33, 438. (1) Liu, D.; Sarrafpour, S.; Guo, W.; Goulart, B.; Bennett, C. S. J. Carbohydr. Chem. 2014, 33, 423. (m) Zhu, D.; Baryal, K. N.; Adhikari, S.; Zhu, J. J. Am. Chem. Soc. 2014, 136, 3172. (n) Beale, T. M.; Moon, P. J.; Taylor, M. S. Org. Lett. 2014, 16, 3604.

(20) For recent examples, see: (a) Balmond, E. I.; Coe, D. M.; Galan, M. C.; McGarrigle, E. M. Angew. Chem. Int. Ed. 2012, 51, 9152. (b) Balmond, E. I.; Benito-Alifonso, D.; Coe, D. M.; Alder, R. W.; McGarrigle, E. M.; Galan, M. C. Angew. Chem. Int. Ed. 2014, 53, 8190. (c) Sau, A.; Williams, R.; Palo-Nieto, C.; Franconetti, A.; Medina, S.; Galan, M. C. Angew. Chem. Int. Ed. 2017, 56, 3640. (d) Palo-Nieto, C.; Sau, A.; Galan, M. C. J. Am. Chem. Soc. 2017, 139, 14041. (e) Sherry, B. D.; Loy, R. N.; Toste, F. D. J. Am. Chem. Soc. 2004, 126, 4510. (f) Sau, A.; Palo-Nieto, C.; Galan, M. C. J. Org. Chem. 2019, 84, 2415. (g) Wang, J.; Deng, C.; Zhang, Q.; Chai, Y. Org. Lett. 2019, 21, 1103. (h) Bradshaw, G. A.; Colgan, A. C.; Allen, N. P.; Pongener, I.; Boland, M. B.; Ortin, Y.; McGarrigle, E. M. Chem. Sci. 2019, 10, 508. (i) Tatina, M. B.; Moussa, Z.; Xia, M.; Judeh, Z. M. A. Chem. Commun. 2019, 55, 12204.

(21) For reviews of photoinduced glycosylations, see: (a) Sangwan, R.; Mandal, P. K. RSC Adv. 2017, 7, 26256. (b) Wang, H.; Wu, P.; Zhao, X.; Zeng, J.; Wan, Q. Acta Chim. Sinica 2019, 77, 231. For recent selective examples of visible-light-mediated glycosylations, see: (c) Mao, R.-Z.; Xiong, D.-C.; Guo, F.; Li, Q.; Duan, J.; Ye, X.-S. Org. Chem. Front. 2016, 3, 737. (d) Yu, Y.; Xiong, D.-C.; Mao, R.-Z.; Ye, X.-S. J. Org. Chem. 2016, 81, 7134. (e) Andrews, R. S.; Becker, J. J.; Gagne, M. R. Angew. Chem. Int. Ed. 2010, 49, 7274. (f) Andrews, R. S.; Becker, J. J.; Gagne, M. R. Angew. Chem. Int. Ed. 2012, 51, 4140. (g) Spell, M. L.; Deveaux, K.; Bresnahan, C. G.; Bernard, B. L.; Sheffield, W.; Kumar, R.; Ragains, J. R. Angew. Chem. Int. Ed. 2016, 55, 6515. (h) Spell, M.; Wang, X.; Wahba, A. E.; Connor, E.; Ragains, J. Carbohydr. Res. 2013, 369, 42. (i) Wen, P.; Crich, D. Org. Lett. 2017, 19, 2402. (j) Wever, W. J.; Cinelli, M. A.; Bowers, A. A. Org. Lett. 2013, 15, 30. (k) Ye, H.; Xiao, C.; Zhou, Q.; Wang, P.; Xiao, W.-J.J. Org. Chem. 2018, 83, 13325. 